Case Report

\title{
Multiple Marginal Tissue Recession Treated with a Simplified Lateral Sliding Flap Technique
}

\author{
Fernando Salimon Ribeiro, ${ }^{1}$ Juliana Aparecida Najarro Dearo de Morais-Camillo, ${ }^{2}$ \\ José Marcos Alves Fernandes, ${ }^{3}$ Juliana Rico Pires, ${ }^{1}$ Elizangela Partata Zuza, \\ and Ana Emília Farias Pontes ${ }^{1}$ \\ ${ }^{1}$ Masters of Science Program, Educational Foundation of Barretos, UNIFEB, 14783-226 Barretos, SP, Brazil \\ ${ }^{2}$ Private Practice, 37958-000 Monte Santo de Minas, MG, Brazil \\ ${ }^{3}$ School of Dentistry, Federal University of Goiás, 74605-220 Goiânia, GO, Brazil
}

Correspondence should be addressed to Ana Emília Farias Pontes; anaemiliapontes@yahoo.com.br

Received 30 June 2014; Accepted 2 October 2014; Published 21 October 2014

Academic Editor: Hsein-Kun Lu

Copyright (c) 2014 Fernando Salimon Ribeiro et al. This is an open access article distributed under the Creative Commons Attribution License, which permits unrestricted use, distribution, and reproduction in any medium, provided the original work is properly cited.

\begin{abstract}
Marginal tissue recession is a common esthetic problem that is usually accompanied by dentin sensitivity, and patients frequently report a fear of dental loss. Lateral sliding flaps have been used for localized recession, but they are rarely used for multiple recessions. The aim of this paper was to report a case of coverage of multiple marginal tissue recessions by means of a lateral sliding flap associated with a connective tissue graft. This was a modification of Nelson's technique, which was originally described as the combination of the double papilla technique, lateral sliding flap, and connective tissue graft. In the present case, double papilla was not performed, rendering the maneuver less complicated. After surgery on teeth \#23 to \#25, total root coverage, decreased dentin sensitivity, and increased keratinized tissue band and gingival thickness were achieved. In the present case, modified Nelson technique proved to be a more simple procedure for the treatment of multiple recessions in one session, resulting in adequate healing, predictable root coverage, and, more importantly, esthetic and functional success.
\end{abstract}

\section{Introduction}

Increasing interest in dental esthetics has significantly influenced treatment planning over the past few years. Subsequently, new dental materials and techniques have been developed in order to provide predictable esthetic outcomes. Among esthetic buccal disorders, marginal tissue recessiondue to the loss of marginal gingival tissues, periodontal connective tissue fibers, tooth cementum, and alveolar bonehas garnered particular attention [1].

Marginal tissue recessions are multifactorial and are caused by traumatic tooth-brushing techniques and periodontal disease, not to mention occlusal trauma, the presence of partially removable prosthesis clamps, improper restorations, frenal pull, tooth malposition, extraction, or inadequate incision that can act individually or in combination to initiate the problem $[2,3]$. As a consequence, impaired esthetic appearance, dentin sensitivity, and root caries may occur, and patients often report fear of dental loss [2].

Surgical periodontal techniques include free gingival grafts, connective tissue grafts, coronally positioned flaps, and laterally sliding flaps [4-8]. These techniques can be performed alone or in combination to perform root coverage of multiple recessions during the same procedure with predictable outcomes [9].

For lateral sliding flaps, keratinized tissue from the interdental area is dislocated and positioned over the exposed root, as described by Grupe and Warren Jr. [10] in 1956. This is considered one of most predictable techniques, likely due to the maintenance of a pedicle, which provides a double blood supply at the recipient site, resulting in good color and texture blend [11]. Although mostly used to treat isolated dental 


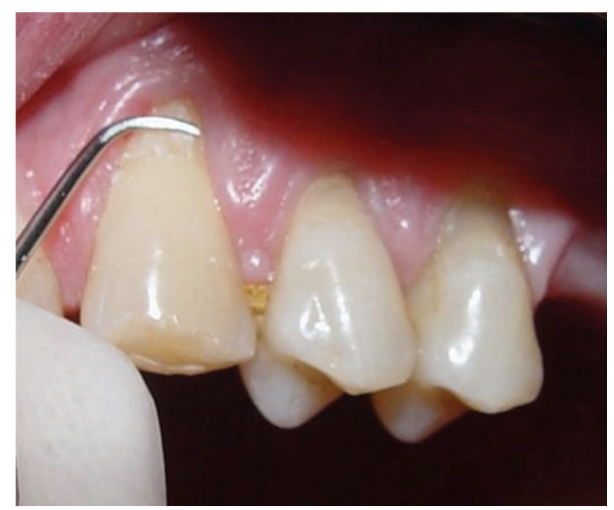

Figure 1: Multiple marginal tissue recessions on teeth \#23, \#24, and \#25 were scaled and planed prior to the surgical procedure.

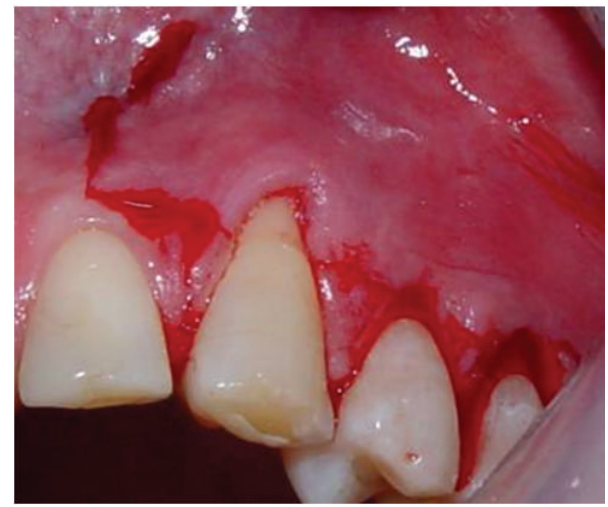

(a)

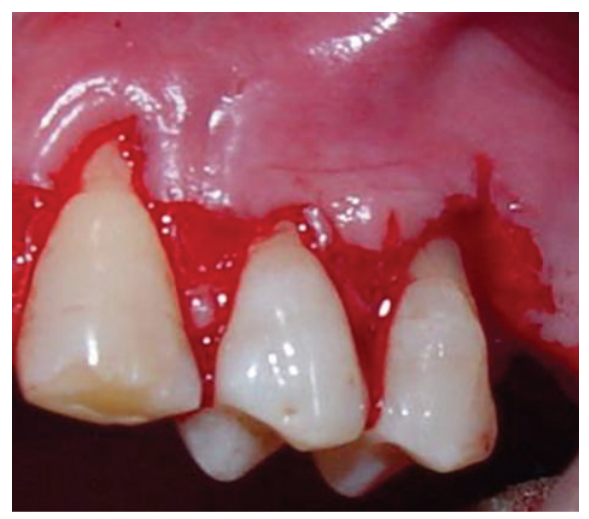

(b)

FIGURE 2: Vertical and horizontal incisions were performed from the mesial portion of (a) tooth \#23 up to (b) tooth \#25.

recessions, Nelson [5] described a technique for multiple root coverage, combining lateral sliding flap, double papilla, and connective tissue graft.

The aim of this paper was to report a case of coverage of multiple marginal tissue recessions by means of a lateral sliding flap associated with a connective tissue graft. This modified, simplified Nelson technique rendered double papilla intervention unnecessary.

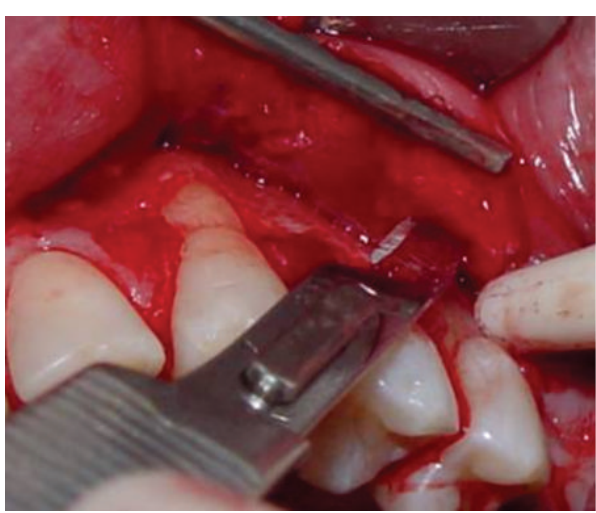

(a)

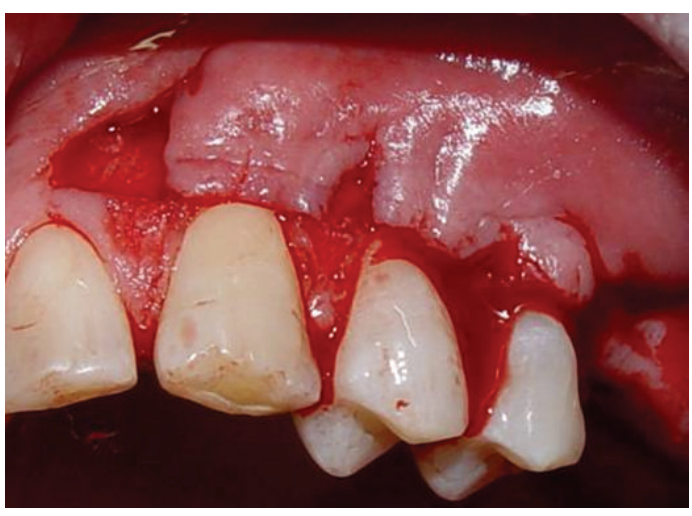

(b)

FIgURE 3: (a) A linear incision was performed on the periosteum at the base of the flap, (b) to allow positioning of the flap without tension before suturing.

\section{Case Report}

A 40-year-old man reported to the Periodontics Clinic of the Araraquara School of Dentistry at the State University of São Paulo (UNESP) with dentin sensitivity in the left upper posterior region. Written consent was obtained, and this report was conducted in full accordance with ethical principles, including the World Medical Association Declaration of Helsinki.

Upon clinical examination, the presence of marginal tissue recessions (Miller Class II) was detected on the buccal aspect of teeth \#23,\#24, and \#25. Traumatic tooth brushing was defined as the primary etiology. In these teeth, the recessions measured $5 \mathrm{~mm}$, and probing depths greater than $3 \mathrm{~mm}$ were not identified; plaque index and sulcular bleeding on probing were less than $20 \%$.

The treatment plan included oral hygiene instruction to adjust the pattern of tooth brushing, and periodontal plastic surgery was scheduled 4 weeks later, by means of connective tissue graft associated with a lateral sliding flap.

On the day of the surgery, extraoral and intraoral antisepsis were performed with a $0.12 \%$ chlorhexidine digluconate solution, and local anesthesia was performed with mepivacaine $2 \% \mathrm{HCl}$ with norepinephrine $(1: 100,000)$. Next, scaling and planning of the exposed roots were performed 


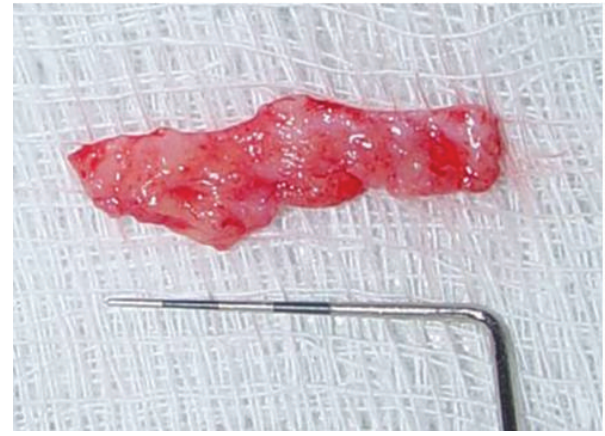

(a)

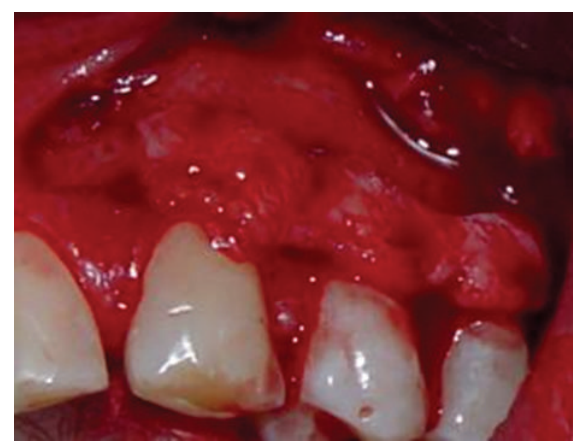

(b)

FIgURE 4: (a) Connective tissue graft was harvested from the palate and (b) positioned over the recipient site.

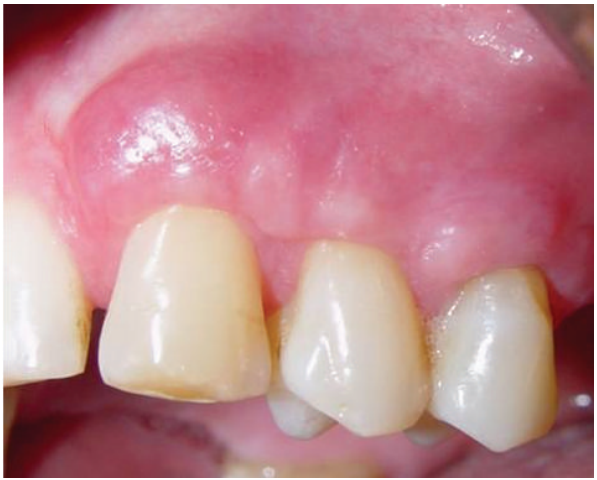

(a)

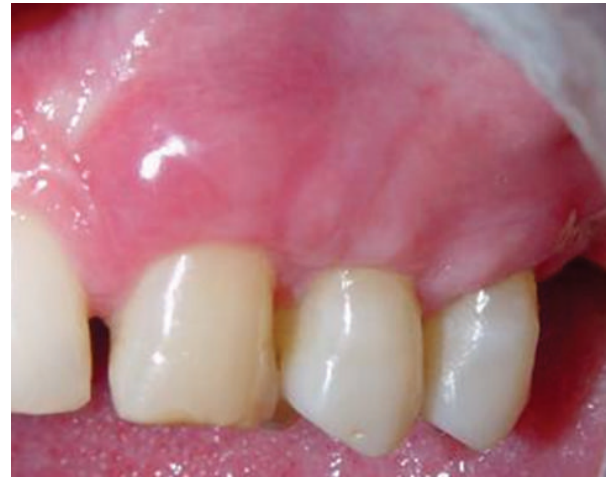

(b)

Figure 5: Clinical aspects of the site (a) 30 days and (b) 8 months after surgery.

using Gracey 7-8 curettes, with the aim of removing infected cementum and preparing the roots for coverage (Figure 1).

A sulcular incision was performed from teeth $\# 23$ to \#25, connected by horizontal incisions on the papilla base. Then, vertical incisions in the mesial surface of tooth \#23 and the distal surface of tooth \#25 were performed (Figure 2). In the apical portion of the vertical incision in the mesial surface of tooth \#23, a cutback incision was performed in order to provide mobility to the flap. Afterwards, a double flap was raised with partial thickness on the mesial portion of tooth \#23 and full thickness in the remaining portions, as proposed by Espinel and Caffesse [12]. A linear incision was performed on the periosteum at the base of the flap to allow for positioning of the flap without tension (as shown in Figure 3), before suturing. A connective tissue graft was obtained from the palate (Figure 4(a)) using the linear technique proposed by Paolantonio [8]. Next, the connective tissue graft was positioned over the recipient site (Figure 4(b)).

Interdental and lateral interrupted, absorbable suture Vicryl 6.0 (Ethicon Inc., Johnson \& Johnson Company, São Bernardo do Campo, SP, Brazil) were used to stabilize the flap. This flap was then laterally advanced to completely cover the connective tissue graft and was stabilized with interrupted mattress 4-0 silk sutures (Ethicon Inc.). In order to stabilize the clot, the donor site was sutured with interrupted " $\mathrm{X}$ " sutures.
Ibuprofen $400 \mathrm{mg}$ was prescribed every 6 hours for 3 days, and $0.12 \%$ chlorhexidine digluconate solution was prescribed twice daily for 2 weeks. Follow-up control sessions were performed weekly during the first month (Figure 5(a)). Seven days after surgery, good healing was noticed on the host and donor sites. Eight months after surgery (Figure 5(b)), esthetic clinical outcome was observed, with complete root coverage and formation of an adequate band of keratinized tissue. The patient was fully satisfied with the functional and esthetic results and reported a significant decrease in dentin sensitivity.

\section{Discussion}

The treatment of marginal tissue recession has been a therapeutic challenge, mainly when dealing with multiple teeth. The combination of techniques, however, allows for the treatment of adjacent recessions in one session $[2,12,13]$.

Lateral sliding flap was chosen in the present case because there was enough volume of keratinized tissue in the interdental areas. Moreover, the combination of lateral sliding flap and connective tissue graft offered the advantages of both techniques. The first technique creates a zone of keratinized gingival tissue and the second technique results in color blending, increased gingival thickness, reduced morbidity in the donor site, and a high degree of root coverage $[8,13$, 
14]. Graft survival using this technique is high because full thickness lateral sliding flaps offer additional vascularization of the graft $[4,6,12,15-17]$. In addition, this type of flap allows keratinized tissue from the papilla to be placed over the area of the recession, increasing the chance of keratinized tissue formation in the surgical area [18-20].

According to Smukler [18], Guinard and Caffesse [19], and Romanos et al. [21], the success of lateral sliding flap when used alone is around $70 \%$ root coverage. However, if lateral sliding flap is associated with connective tissue graft, root coverage reaches around $95 \%$.

The connective tissue graft is considered the gold standard for root coverage procedures [9]. Studies have shown a mean recession defect coverage of $96 \%[8,13,14,20]$. This may be attributed to the increase in gingival thickness due to the connective tissue graft. On the other hand, one disadvantage, especially with respect to multiple recessions, is that the patient can experience pain in the donor area. This is related to the surgical technique used and the volume of the removed graft. In the present case, a linear technique that maintains tissue with blood irrigation and decreases the risk of necrosis was used to minimize this disadvantage [7].

During the postoperative period, our patient reported a decrease in dentin sensitivity. Harris [6] also reported a decrease in dentin sensitivity in 68 of the 100 cases studied. Thus, dentin sensitivity in recession areas can be an indication for the use of surgical procedures $[3,4,6,8,12,15-17]$.

Thus, in the present case, the modified Nelson technique resulted in the treatment of multiple recessions in a single procedure, resulting in adequate healing, predictable root coverage, and, more importantly, esthetic and functional success.

\section{Conflict of Interests}

The authors declare no conflict of interests regarding the publication of this paper.

\section{References}

[1] G. A. Santarelli, R. Ciancaglini, F. Campanari, C. Dinoi, and S. Ferraris, "Connective tissue grafting employing the tunnel technique: a case report of complete root coverage in the anterior maxilla," International Journal of Periodontics and Restorative Dentistry, vol. 21, no. 1, pp. 77-83, 2001.

[2] T. F. Tözüm and F. M. Dini, "Treatment of adjacent gingival recessions with subepithelial connective tissue grafts and the modified tunnel technique," Quintessence International, vol. 34, no. 1, pp. 7-13, 2003.

[3] A. Borghetti and F. Louise, "Controlled clinical evaluation of the subpedicle connective tissue graft for the coverage of gingival recession," Journal of Periodontology, vol. 65, no. 12, pp. 11071112, 1994.

[4] M. C. Espinel and R. G. Caffesse, "Lateral positioned pedicle sliding flap-revised technique in the treatment of localized gingival recessions," The International Journal of Periodontics \& Restorative Dentistry, vol. 1, no. 5, pp. 42-51, 1981.

[5] S. W. Nelson, "The subpedicle connective tissue graft. A bilaminar reconstructive procedure for the coverage of denuded root surfaces.", Journal of Periodontology, vol. 58, no. 2, pp. 95-102, 1987.

[6] R. J. Harris, "The connective tissue and partial thickness double pedicle graft: a predictable method of obtaining root coverage.," Journal of Periodontology, vol. 63, no. 5, pp. 477-486, 1992.

[7] J. F. Bruno, "Connective tissue graft technique assuring wide root coverage," The International Journal of Periodontics \& Restorative Dentistry, vol. 14, no. 2, pp. 126-137, 1994.

[8] M. Paolantonio, "Treatment of gingival recessions by combined periodontal regenerative technique, guided tissue regeneration, and subpedicle connective tissue graft. A comparative clinical study," Journal of Periodontology, vol. 73, no. 1, pp. 53-62, 2002.

[9] J. G. Woodyard, H. Greenwell, M. Hill, C. Drisko, J. M. Iasella, and J. Scheetz, "The clinical effect of acellular dermal matrix on gingival thickness and root coverage compared to coronally positioned flap alone," Journal of Periodontology, vol. 75, no. 1, pp. 44-56, 2004.

[10] H. E. Grupe and R. F. Warren Jr., "Repair of gingival defects by a sliding flap operation," Journal of Periodontology, vol. 27, no. 2, pp. 92-95, 1956.

[11] J. L. Wennström, "Mucogingival therapy," Annals of Periodontology, vol. 1, no. 1, pp. 671-701, 1996.

[12] M. C. Espinel and R. G. Caffesse, "Comparison of the results obtained with the laterally positioned pedicle sliding flaprevised technique and the lateral sliding flap with a free gingival graft technique in the treatment of localized gingival recessions," The International Journal of Periodontics \& Restorative Dentistry, vol. 1, no. 6, pp. 30-37, 1981.

[13] I. Zabalegui, A. Sicilia, J. Cambra, J. Gil, and M. Sanz, "Treatment of multiple adjacent gingival recessions with the tunnel subepithelial connective tissue graft: a clinical report," The International Journal of Periodontics and Restorative Dentistry, vol. 19, no. 2, pp. 199-206, 1999.

[14] L. Langer and B. Langer, "The subepithelial connective tissue graft for treatment of gingival recession," Dental Clinics of North America, vol. 37, no. 2, pp. 243-264, 1993.

[15] R. J. Harris, "The connective tissue with partial thickness double pedicle graft: the results of 100 consecutively-treated defects," Journal of Periodontology, vol. 65, no. 5, pp. 448-461, 1994.

[16] R. J. Harris, "A comparative study of root coverage obtained with guided tissue regeneration utilizing a bioabsorbable membrane versus the connective tissue with partial-thickness double pedicle graft," Journal of Periodontology, vol. 68, no. 8, pp. 779790, 1997.

[17] R. J. Harris, "A comparison of two techniques for obtaining a connective tissue graft from the palate," International Journal of Periodontics and Restorative Dentistry, vol. 17, no. 3, pp. 261-271, 1997.

[18] H. Smukler, "Laterally positioned mucoperiosteal pedicle grafts in the treatment of denuded roots. A clinical and statistical study," Journal of Periodontology, vol. 47, no. 10, pp. 590-595, 1976.

[19] E. A. Guinard and R. G. Caffesse, "Treatment of localized gingival recessions. Part III. Comparison of results obtained with lateral sliding and coronally repositioned flaps," Journal of Periodontology, vol. 49, no. 9, pp. 457-461, 1978.

[20] A. L. Allen, "Use of the supraperiosteal envelope in soft tissue grafting for root coverage. II. Clinical results," The International Journal of Periodontics \& Restorative Dentistry, vol. 14, no. 4, pp. 302-315, 1994. 
[21] G. E. Romanos, J. P. Bernimoulin, and E. Marggraf, "The double lateral bridging flap for coverage of denuded root surface: longitudinal study and clinical evaluation after 5 to 8 years," Journal of Periodontology, vol. 64, no. 8, pp. 683-688, 1993. 


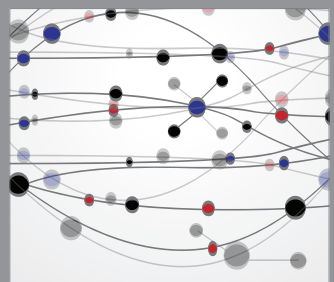

The Scientific World Journal
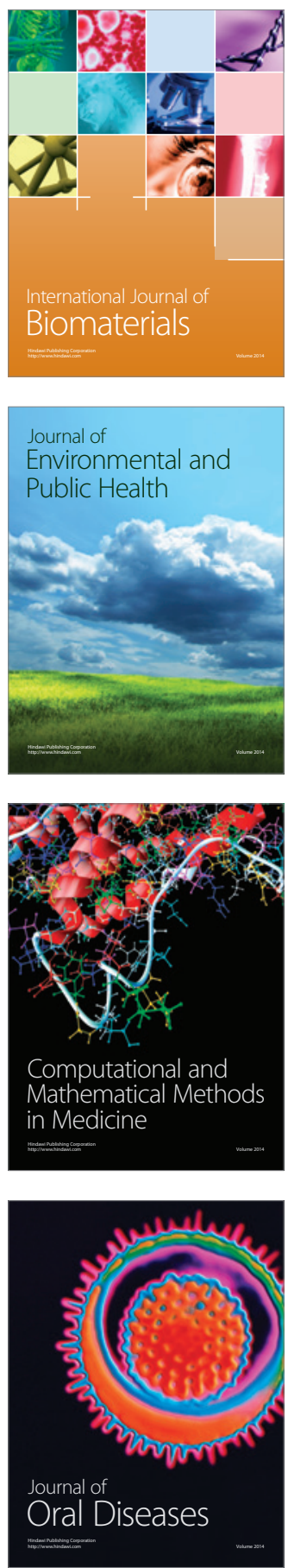
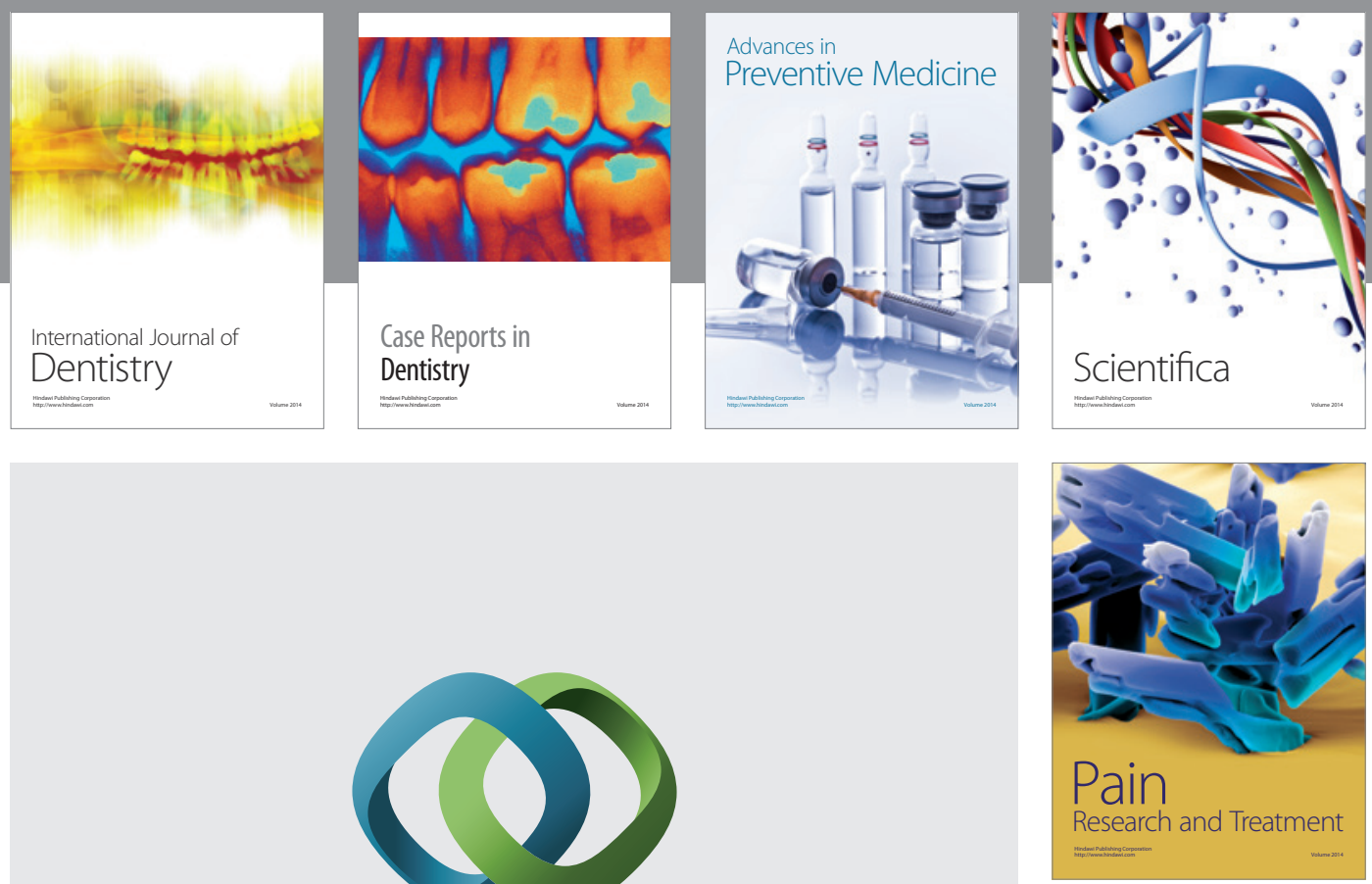

\section{Hindawi}

Submit your manuscripts at

http://www.hindawi.com
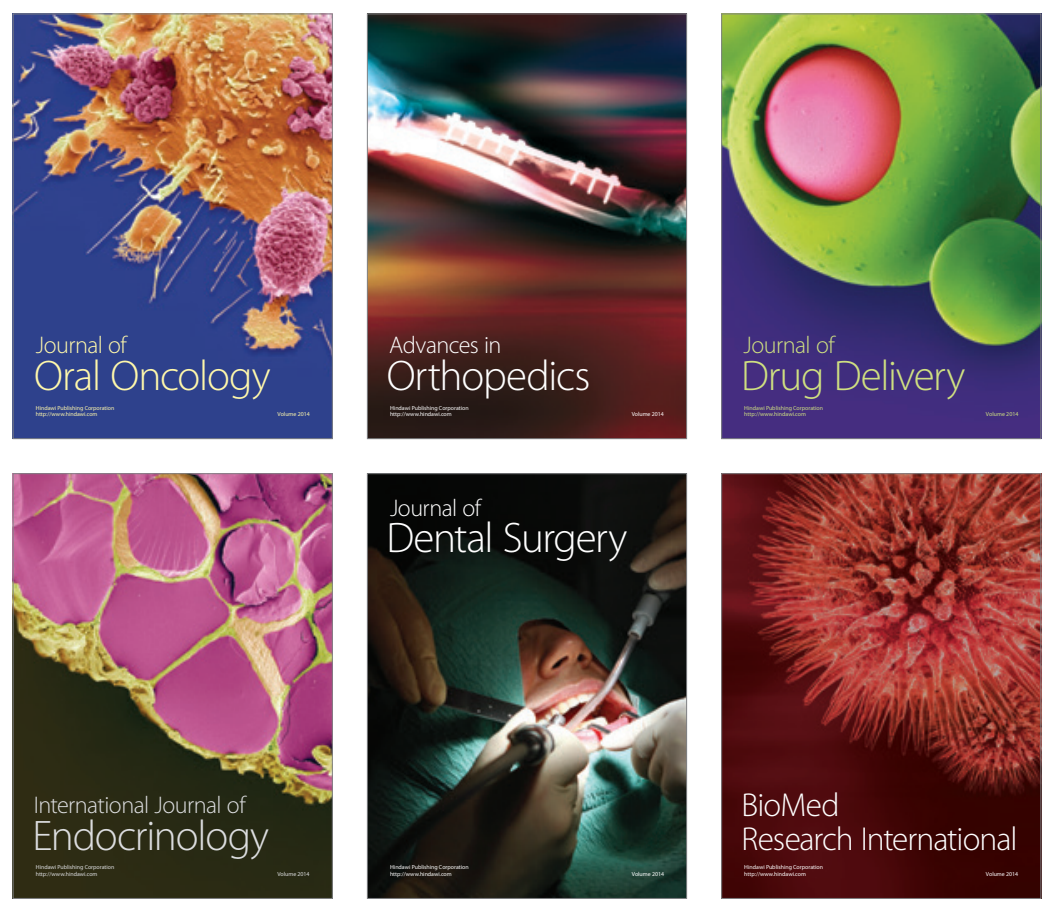

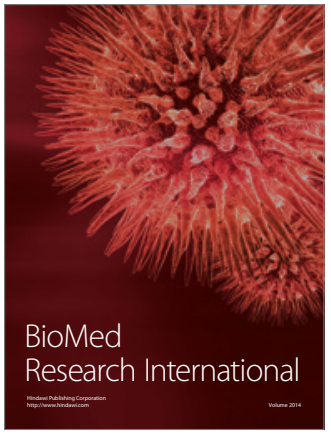

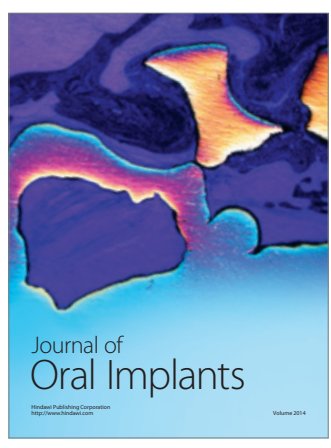
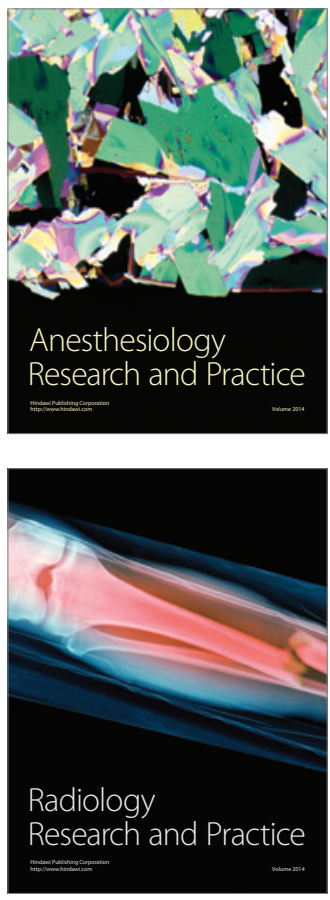